\title{
Synthesis and In Vitro and In Vivo Evaluation of a New ${ }^{68}$ Ga-Semicarbazone Complex: Potential PET Radiopharmaceutical for Tumor Imaging
}

\author{
N. S. Al-Hokbany, ${ }^{1}$ Basim Alotaibi, ${ }^{2}$ Suad Bin Amer, ${ }^{2}$ \\ Subhani M. Okarvi, ${ }^{2}$ and Ibrahim Al-Jammaz ${ }^{2}$ \\ ${ }^{1}$ Chemistry Department, School of Science, King Saud University, Riyadh, Saudi Arabia \\ ${ }^{2}$ Cyclotron and Radiopharmaceuticals Department, King Faisal Specialist Hospital and Research Centre, \\ P.O. Box 3354, Riyadh 11211, Saudi Arabia
}

Correspondence should be addressed to Ibrahim Al-Jammaz; jammaz@kfshrc.edu.sa

Received 30 December 2013; Revised 20 July 2014; Accepted 5 August 2014; Published 8 September 2014

Academic Editor: Doina Humelnicu

Copyright (c) 2014 N. S. Al-Hokbany et al. This is an open access article distributed under the Creative Commons Attribution License, which permits unrestricted use, distribution, and reproduction in any medium, provided the original work is properly cited.

In an attempt to develop new tumor imaging radiotracers with favorable biochemical properties, we have synthesized new ${ }^{68} \mathrm{Ga}$ 2-acetylpyridine semicarbazone $\left({ }^{68} \mathrm{Ga}\right.$ - $\left.[\mathrm{APSC}]_{2}\right)$ as a potential positron emission tomography (PET) tumor imaging agent using a straightforward and a one-step simple reaction. Radiochemical yield and purity were quantitative without HPLC purification. Biodistribution studies in nude mice model bearing human MDA-MB-231 cell line xenografts displayed significant tumor uptake of ${ }^{68} \mathrm{Ga}-[\mathrm{APSC}]_{2}$ radiotracer after $2 \mathrm{~h}$ postinjection (p.i.). The initial results demonstrate that ${ }^{68} \mathrm{Ga}-[\mathrm{APSC}]_{2}$ radiotracer may be useful probe for detecting and staging of hypoxic tumor using PET imaging modality.

\section{Introduction}

The physical properties of the positron emitter gallium$68\left({ }^{68} \mathrm{Ga}\right)$ and its availability from ${ }^{68} \mathrm{Ge} /{ }^{68} \mathrm{Ga}$ generator, together with the well-known coordination chemistry of gallium, make it one of the most attractive radionuclides for PET imaging. Therefore, varieties of ${ }^{68} \mathrm{Ga}$-labeled bioactive molecules for potential use beyond the measurement of glucose metabolism were developed and investigated [13]. This development will certainly help nuclear medicine centers without the on-site availability of a cyclotron and consequently patient care improvement.

Heterocyclic thiosemicarbazones, semicarbazones, and their metal complexes have been extensively investigated as potential antitumor agents [4-12]. Most studied thiosemicarbazones and semicarbazones were the pyridine-based compounds which might be attributed to their resemblance to pyridoxal metabolites that attached to coenzyme B6dependent enzymes and caused enzyme inhibition [4, 11]. Varieties of metallic PET and single photon emission computed tomography (SPECT) radionuclides were incorporated into thiosemicarbazones chelates. Among these radionuclides, ${ }^{67 / 68} \mathrm{Ga}$ and copper-62/64 $\left({ }^{62 / 64} \mathrm{Cu}\right)$ have shown considerable success for targeting hypoxic and normoxic tumor xenografts in athymic mouse models [12-19].

Recently, radiolabeled ${ }^{67} \mathrm{Ga}$-thiosemicarbazone complex was synthesized with high radiochemical yield and purity. Biodistribution study in fibrosarcoma bearing mice revealed specific tumor accumulation after $2 \mathrm{~h}$ postinjection (p.i.) which may suggest that ${ }^{68} \mathrm{Ga}$ is a better candidate for tumor imaging than ${ }^{67} \mathrm{Ga}[20]$.

Due to the well-known coordination chemistry of gallium, high stability of $\mathrm{Ga}^{\mathrm{III}}$-semicarbazone in comparison with its thiosemicarbazone complexes [4], and its enhanced 
antineoplastic activity, we were interested in developing new radiotracers with favorable biochemical properties; we here report the synthesis, characterization, and preclinical evaluation of new ${ }^{68} \mathrm{Ga}$-2-acetylpyridine semicarbazone $\left({ }^{68} \mathrm{Ga}\right.$ $\left[\mathrm{APSC}_{2}\right.$ ) as a potential PET imaging agent for hypoxic tumor.

\section{Experimental}

2.1. Materials and Measurements. The chemicals used in the study were all of analytical reagent grade, were purchased from Aldrich, and were used without further purification unless stated. Commercial ${ }^{68} \mathrm{Ga}$-generator based on a $\mathrm{SnO}_{2}$ phase adsorbing was obtained from iThemba Lab, South Africa. ${ }^{67} \mathrm{Ga}$ was produced by the bombardment of enriched zinc-68 $\left({ }^{68} \mathrm{Zn}\right)$ targets $(1 \mathrm{~g} \pm 10 \%)$ with $30 \mathrm{MeV}$ protons from the Cyclone 30 cyclotron internal beam using the ${ }^{68} \mathrm{Zn}$ (p, 2n) ${ }^{67} \mathrm{Ga}$ nuclear process. Sep-Pak cartridges were purchased from Waters-Millipore. TLC-SG sheets were purchased from Grace Sciences Inc. High Performance Liquid Chromatography (HPLC) analysis was carried out on Luna, Phenomenex C-18 reversed phase column (analytical, $250 \mathrm{~mm} \times 4.6 \mathrm{~mm}$ ). The solvent system used was isocratic (eluent: $\mathrm{ACN} / \mathrm{H}_{2} \mathrm{O}$ 95/5, with $0.1 \%$ TFA at flow rate of $1.0 \mathrm{~mL} / \mathrm{min}$ ). A Jasco chromatographic system equipped with a variable wavelength ultraviolet monitor and in tandem with a Canberra flow through radioactivity detector was used. Ultraviolet absorption was monitored at $254 \mathrm{~nm}$. Chromatograms were acquired and analyzed using BORWIN software. Melting points were determined on a Thomas-Hoover Unimelt capillary melting point apparatus. Mass spectroscopy was run on Quattra electrospray mass spectrometer (ES-MS). Elemental analyses were performed on a Perkin Elmer CHN 2400 analyzer. IR bands were recorded on a Perkin Elmer spectrophotometer 1000 in the spectral range $200-4000 \mathrm{~cm}^{-1}$ with sample in the form of $\mathrm{KBr}$ pellets. ${ }^{1} \mathrm{H}-{ }^{13} \mathrm{C}$ NMR spectra were obtained in DMSO-D 6 on JEOL NMR $400 \mathrm{MHz}$. Log K was calculated by potentiometric methods as described in the literature [21].

2.2. 2-Acetylpyridine Semicarbazone (APSC). APSC compound was synthesized using method reported previously [22]. In brief, aqueous solution $(20 \mathrm{~mL})$ of semicarbazide hydrochloride $(1.11 \mathrm{~g}, 1.0 \mathrm{mmol})$ was added to aqueous solution $(20 \mathrm{~mL})$ of 2 -acetyl pyridine $(1.20 \mathrm{~g}, 1.0 \mathrm{mmol})$ in the presence of sodium acetate $(1.36 \mathrm{gm}, 1.0 \mathrm{mmol})$. The reaction mixture was stirred vigorously for $2 \mathrm{~h}$. The crystalline white product was filtered off and washed with ether. Yield: $96 \%$, $\mathrm{mp}=188-192^{\circ} \mathrm{C}$. $\left[\mathrm{C}_{8} \mathrm{H}_{10} \mathrm{~N}_{4} \mathrm{O}\right]$ elemental analysis (calculated): C: 54.0 (53.9\%), H: 5.8 (5.7\%), and N: 31.2 (31.4\%). IR $\left(v_{\max } / \mathrm{cm}^{-1}\right):(\mathrm{NH}: 3473) ;\left(\mathrm{NH}_{2}: 3375\right) ;\left(\mathrm{CH}_{3}: 2280\right) ;\left(\mathrm{C}=\mathrm{O}_{\mathrm{as}}\right.$ : 1686); $\left(\mathrm{C}=\mathrm{O}_{\text {sy }}\right.$ : 1579); (C=N: 1443); (C-O: 1104); (heterocyclic bases: 771, 626, 561, and 448). NMR ( ${ }^{1} \mathrm{H}$, ppm, DMSO-d6): $3.39\left(3 \mathrm{H}, \mathrm{CH}_{3}\right) ; 7.3\left(2 \mathrm{H}, \mathrm{NH}_{2}\right) ; 7.3(1 \mathrm{H}, \mathrm{CH}=\mathrm{C}) ; 7.7(1 \mathrm{H}$, $\mathrm{CH}=\mathrm{C}) ; 8.3(1 \mathrm{H}, \mathrm{CH}-\mathrm{C}) ; 8.5(1 \mathrm{H}, \mathrm{CH}-\mathrm{N}) ; 9.5(1 \mathrm{H}, \mathrm{NH}) .\left({ }^{13} \mathrm{C}-\right.$ ppm, DMSO-d6): $12\left(\mathrm{CH}_{3}\right) ; 120.7$ (C-H); 123.8 (C-HC); 136
$(\mathrm{C}-\mathrm{H}) ; 145(\mathrm{C}=\mathrm{N}) ; 148(\mathrm{C}-\mathrm{HD}) ; 155(\mathrm{C}-\mathrm{N}=\mathrm{C}) ; 157(\mathrm{C}=\mathrm{O})$. $m / z\left(\mathrm{ESI}^{+}\right) 179\left([\mathrm{M}]^{+}\right)$.

2.3. 2-Acetylpyridine Semicarbazone Ga-Complex (Ga$[\mathrm{APSC}]_{2}$ ). Ga-[APSC $]_{2}$ complex was prepared according to previously published method with slight modification [22]. To the ligand APSC $(0.019 \mathrm{~g}, 0.106 \mathrm{mmol})$, dissolved in hot ethanol (EtOH, $10 \mathrm{~mL}$ ), was added $\mathrm{GaCl}_{3}$ in $\mathrm{EtOH}$ solution $(1 \mathrm{~mL}, 0.05 \mathrm{mmol})$ drop-wise. The reaction mixture was refluxed for $2 \mathrm{~h}$ under $\mathrm{N}_{2}$ atmosphere with vigorous stirring. The reaction mixture cooled down to room temperature and kept under $\mathrm{N}_{2}$ atmosphere until the yellow-white product precipitated. Precipitate was then filtered and washed with ether. Yield: $66 \%$. M.P. $=207^{\circ}$ C. $\left[\mathrm{C}_{16} \mathrm{H}_{20} \mathrm{~N}_{8} \mathrm{O}_{2} \mathrm{Cl} \mathrm{Ga}, \mathrm{Mr}\right.$ 461] elemental analysis (calculated): C: 41.3 (41.6\%), H: 4.6 (4.3\%), N: $24.4(24.3 \%)$, and $\mathrm{Cl} 15.56(15.1 \%)$. IR $\left(v_{\max } / \mathrm{cm}^{-1}\right)$ : $(\mathrm{NH}, 3444) ;\left(\mathrm{NH}_{2}: 3245\right) ;\left(\mathrm{CH}_{3}: 2365\right) ;\left(\mathrm{C}=\mathrm{O}_{\mathrm{as}}: 1678\right) ;(\mathrm{C}=\mathrm{N}$ : 1528); (C-O: 1066); (Ga-N: 540); (Ga-O: 470), 3114 (C-H). NMR ( ${ }^{1} \mathrm{H}$, ppm, DMSO-d6): $1.08\left(3 \mathrm{H}, \mathrm{CH}_{3}\right) ; 7.3\left(2 \mathrm{H}, \mathrm{NH}_{2}\right)$; $7.6(1 \mathrm{H}, \mathrm{CH}=\mathrm{C}) ; 8.1(1 \mathrm{H}, \mathrm{CH}=\mathrm{C}) ; 8.3(1 \mathrm{H}, \mathrm{CH}-\mathrm{C}) ; 8.7(1 \mathrm{H}$, $\mathrm{CH}-\mathrm{N}) ; 9.8(1 \mathrm{H}, \mathrm{NH}) .\left({ }^{13} \mathrm{C}-\mathrm{ppm}, \mathrm{DMSO}-\mathrm{d} 6\right): 15\left(\mathrm{CH}_{3}\right) ; 120.7$ $(\mathrm{CH}-\mathrm{C}) ; 123.8(\mathrm{C}=\mathrm{C}) ; 136(\mathrm{C}=\mathrm{C}) ; 146(\mathrm{C}=\mathrm{N}) ; 148(\mathrm{C}-\mathrm{N}) ; 157$ $(\mathrm{C}-\mathrm{N}=\mathrm{C}) ; 65(\mathrm{C}-\mathrm{O}) \cdot \mathrm{m} / z\left(\mathrm{ESI}^{+}\right) 427\left([\mathrm{M}]^{+}\right) . \log K=22$.

2.4. Radiochemistry. ${ }^{68} \mathrm{Ge} /{ }^{68} \mathrm{Ga}$ generator was eluted with suprapure $\mathrm{HCl}(0.6 \mathrm{M}, 6 \mathrm{~mL})$ in $0.5 \mathrm{~mL}$ fractions. The two fractions with the highest ${ }^{68} \mathrm{GaCl}_{3}$ (37-300 MBq) activity were generally used for labeling purposes [23, 24]. The ${ }^{68} \mathrm{Ga}$-[APSC] $]_{2}$ complex was prepared by the addition of APSC $(50 \mu \mathrm{g})$ to a screw-cap vial containing ${ }^{68} \mathrm{GaCl}_{3}$ $(185-300 \mathrm{MBq})$ dissolved in $0.1 \%$ acetic acid/methanol $(\mathrm{AcOH} / \mathrm{MeOH}, \mathrm{v} / \mathrm{v} ; \mathrm{pH}=4.5)$. The reaction mixture was heated for $30 \mathrm{~min}$ at $90^{\circ} \mathrm{C}$ and cooled to room temperature, followed by the dilution with normal saline, and the product was passed via a $0.22 \mu \mathrm{m}$ membrane filter to be ready for injection. The same procedure was repeated with ${ }^{67} \mathrm{Ga}$ $[\mathrm{APSC}]_{2}$.

2.5. Stability in Plasma. For stability in plasma, ${ }^{68} \mathrm{Ga}-$ [APSC] $]_{2}$ complex $(100 \mu \mathrm{L}, 20 \mu \mathrm{Ci}$ each) was incubated with human plasma $(500 \mu \mathrm{L})$ in duplicate at $37^{\circ} \mathrm{C}$ for $1-4 \mathrm{~h}$. This was followed by precipitation using a mixture of ACN/EtOH $(400 \mu \mathrm{L}, 1 / 1 \mathrm{v} / \mathrm{v})$ and centrifugation at $5000 \mathrm{rpm}$ for $5 \mathrm{~min}$. The supernatant layer was then analyzed by HPLC under the conditions described above.

2.6. In Vivo Biodistribution and Tumor Targeting. Approval for the animal protocol used in this study was obtained from the Institutional Animal Care and Use Committee. Animal biodistribution experiments were performed according to the international regulations governing the safe and humane use of laboratory animals in research [25]. MDA-MB-231 breast cancer cell line is known to be induced by hypoxic tumor cells [26]. Human MDA-MB-231 xenograft mouse models were used for in vivo tumor targeting experiments. For the implantation of tumor xenografts, approximately $3 \times$ $10^{6}$ MDA-MB-231 cells in suspension of $100 \mu \mathrm{L}$ sterile saline 
were injected subcutaneously into the right thigh of each mouse as reported in the literature [27]. Tumors were allowed to grow for 2-3 weeks in which tumors had reached weights of $\sim 500 \mathrm{mg}$. Mice were injected via the lateral tail vein with $100 \mu \mathrm{L}$ of the radiotracers formulated in saline. Each dose contained $\sim 20 \mu \mathrm{Ci}(740 \mathrm{kBq})$ of the ${ }^{68} \mathrm{Ga}-[\mathrm{APSC}]_{2}$ radiotracer. Animals were sacrificed at different time intervals (4 mice at each interval) and tissues of interest were dissected, weighed, and assayed for radioactivity. The percentage of the injected dose per gram $(\% \mathrm{ID} / \mathrm{g})$ was then calculated by counting all tissues in a $\gamma$-well counter using a stored sample of the injection solution as a standard to estimate the total dose injected per mouse.

2.7. Statistical Analysis. Data are expressed as mean \pm S.D. where appropriate. For data comparisons, Student's $t$-test was performed for the mean values using Graph-Pad Software (Graph-Pad Software Inc., San Diego, CA, USA). A probability value of $P<.05$ was considered statistically significant.

\section{Results and Discussion}

3.1. Organic Chemistry. The one-step synthesis of the monosemicarbazones proceeds by the reaction of 2 acetylpyridine and semicarbazides in the presence of acetic acid in aqueous media. Similarly, the reaction of APSC with $\mathrm{GaCl}_{3}$ has furnished Ga-[APSC $]_{2}$ complex in good yield as shown in Scheme 1. Elemental analysis measurements for APSC ligand and Ga- $[\mathrm{APSC}]_{2}$ reference complex were found to correspond to the calculated results. Chemical purity of Ga- $[\mathrm{APSC}]_{2}$ complex was found to be greater than $99 \%$ as represented by a single peak in the HPLC chromatogram with 12.5 min retention time (Figure 1).

The IR bands in the region $3160-3440 \mathrm{~cm}^{-1}$, attributed to the symmetrical stretching mode $v\left(\mathrm{NH}_{2}\right)$ in the spectra of the ligand, were shifted to $3460-3210 \mathrm{~cm}^{-1}$ in those of the complex. The coordination of the ligand $\mathrm{APSC}^{-}$via the azomethine nitrogen is reflected by the shift of $v(\mathrm{C}=\mathrm{N})$ band at $1443 \mathrm{~cm}^{-1}$ to higher frequency at $1528 \mathrm{~cm}^{-1}$ for Ga- $[\mathrm{APSC}]_{2}$ complex and complexation viathe $\mathrm{C}=\mathrm{O}$ strong bands at $1678 \mathrm{~cm}^{-1}$ and $1579 \mathrm{~cm}^{-1}$ was attributed to $v(\mathrm{C}=\mathrm{O})$ asy-, symmetrical, respectively. The $v(\mathrm{CN})$ band for $\mathrm{APSC}^{-}$ also shifted to higher frequency at $1497 \mathrm{~cm}^{-1}$ for the Ga$[\mathrm{APSC}]_{2}$ complex, indicating coordination of the ligand viathe pyridine nitrogen atom. Medium intensity bands at 540 and $470 \mathrm{~cm}^{-1}$ were assigned to stretching vibrations $v(\mathrm{Ga}-\mathrm{N})$ and $v(\mathrm{Ga}-\mathrm{O})$, respectively, whereas weak bands at 771,626 , and $561 \mathrm{~cm}^{-1}$ were assigned to heterocyclic ring.

The NMR spectra of the ligand APSC ${ }^{-}$and its $\mathrm{Ga}$ (III) complex were recorded in DMSO-d6. The coordination of two tridentate monoanionic ligands to $\mathrm{Ga}$ (III) through oxygen and azomethine nitrogen atoms resulted in upfield shifts of two quaternary carbon atoms bound to oxygen atoms from $157 \mathrm{ppm}$ for APS to 65 for Ga-[APSC] ${ }_{2}$ and downfield shifts of the methyl carbons bound to the azomethine groups from $12.15 \mathrm{ppm}$ for $\mathrm{APS}^{-}$to 15.16 and $14.18 \mathrm{ppm}$ for the pyridine rings of Ga-[APSC $]_{2}$. The carbons ortho to the nitrogen atom were shifted upfield correspondingly by 8.1 and $7.7 \mathrm{ppm}$ for $\mathrm{Cl}$ and $\mathrm{C} 2$ and 7.3 and $8.5 \mathrm{ppm}$ for $\mathrm{C} 3$ and $\mathrm{C} 4$, which indicates involvement of the pyridine nitrogen atoms in coordination with $\mathrm{Ga}(\mathrm{III})$.

The ES mass spectrum of Ga-[APSC $]_{2}$ complex recorded in the positive mode showed a $100 \%$ relative intensity (R.I.) peak at $m / z 427$ which corresponds to the theoretical isotopic distribution excluding chloride counter ion.

3.2. Radiochemistry. Due to the well-known coordination chemistry of $\mathrm{Ga}$ (III), high stability of $\mathrm{Ga}$ (III)-semicarbazone complexes, and their enhanced antineoplastic activity and in an attempt to develop new radiotracers with favorable biochemical properties for hypoxic tumor imaging, we synthesize ${ }^{67 / 68} \mathrm{Ga}-[\mathrm{APSC}]_{2}$ as a potential PET and SPECT tumor imaging agent. The synthetic approaches for the preparation of ${ }^{68} \mathrm{Ga}$-APSC chelates were simple and straightforward and gave ${ }^{68} \mathrm{Ga}$ - $[\mathrm{APSC}]_{2}$ complexes in quantitative radiochemical yields and purities as assessed by TLC and HPLC in less than $60 \mathrm{~min}$. The $R_{f}$ values for ${ }^{68} \mathrm{GaCl}_{3}$ and ${ }^{68} \mathrm{Ga}-[\mathrm{APSC}]_{2}$ complex were 0.0 and 0.9 , respectively (Figure 2), and the retention times for the same compounds were 4.12 and $12.70 \mathrm{~min}$, respectively (Figure 3 ), which correspond to the reference sample (Figure 1).

3.3. Stability in Plasma. The proteolytic degradation of the ${ }^{68} \mathrm{Ga}$-[APSC $]_{2}$ complex was determined in human plasma in vitro. The proteolytic degradation of the ${ }^{68} \mathrm{Ga}-[\mathrm{APSC}]_{2}$ complex revealed that this complex remained sufficiently stable ( $>95 \%)$ during incubation at $37^{\circ} \mathrm{C}$ for at least $1 \mathrm{~h}$ and then started degrading to 75 and almost $50 \%$ after 2 and $4 \mathrm{~h}$ of incubation, respectively.

3.4. In Vivo Biodistribution and Tumor Uptake. The biodistribution data in nude mice bearing human MDA-MB-231 cell line xenografts at 1,2 , and $4 \mathrm{~h}$ p.i. ( $n=4$ for each time point) for ${ }^{68} \mathrm{Ga}-[\mathrm{APSC}]_{2}$ radiotracer and $24 \mathrm{~h}$ p.i. for ${ }^{67} \mathrm{Ga}$ - $[\mathrm{APSC}]_{2}$ are shown in Table 1 . The biodistribution data indicate that the radiolabeled compound showed high initial uptake in the blood that reduced with time. At $4 \mathrm{~h}$ p.i., only $3.45 \% \mathrm{ID} / \mathrm{g}$ was presented in the blood circulation. The uptake in the major organs such as the liver, lungs, heart, spleen, and kidneys was also high at 1 and $2 \mathrm{~h}$ p.i. but radioactivity was cleared by these organs and no significant retention of radioactivity was observed at $24 \mathrm{~h}$ p.i., with the exception of kidneys which retained somewhat high radioactivity (up to $6.15 \% \mathrm{ID} / \mathrm{g}$ ) at $24 \mathrm{~h}$ p.i. The uptake in the tumor was somewhat moderate at $1 \mathrm{~h}$ p.i but reached the maximum $(11.58 \pm 1.07 \% \mathrm{ID} / \mathrm{g})$ at $2 \mathrm{~h}$ p.i. At 4 and $24 \mathrm{~h}$ p.i., $4.08 \% \mathrm{ID} / \mathrm{g}$ and $2.22 \% \mathrm{ID} / \mathrm{g}$ of radioactivity, respectively, were found in the tumor indicating a good retention of the radioactivity by the MDA-MB-231 tumors. The tumor-to-muscle ratio obtained at $2 \mathrm{~h}$ p.i. was 7.52. It is worth mentioning here that the tumor uptake value obtained with this radiotracer is found to be similar to the uptake profile reported earlier for ${ }^{67} \mathrm{Ga}$-thiosemicarbazone [20] and the tumor uptake washed out after $24 \mathrm{~h}$ p.i. indicating the opposite to the free ${ }^{68} \mathrm{Ga}$ (III) cation that usually 
<smiles>CC(=O)c1ccccn1</smiles><smiles>C/C(=N/NC(N)=O)c1cccc(/C(C)=N\NC(N)=O)n1</smiles>

Scheme 1: Synthesis of 2-actylpyridine semicarbazone (APSC) and Ga-2-acetylpyridine semicarbazone (Ga-[APSC $]_{2}$ ) complexes $\left(\mathrm{Ga}={ }^{\mathrm{nat} / 67 / 68} \mathrm{Ga}\right)$.

TABLE 1: Biodistribution of ${ }^{68} \mathrm{Ga}$-(2-acetylpyridine semicarbazone $){ }_{2}$ complex $\left({ }^{68} \mathrm{Ga}\right.$ - $\left.[\mathrm{APSC}]_{2}\right)$ in tumor bearing nude mice.

\begin{tabular}{lcccc}
\hline & $1 \mathrm{~h}$ & $2 \mathrm{~h}$ & $4 \mathrm{~h}$ & $24 \mathrm{~h}^{*}$ \\
\hline Blood & $17.71 \pm 1.33$ & $6.41 \pm 0.10$ & $3.45 \pm 0.57$ & $2.13 \pm 0.08$ \\
Liver & $7.04 \pm 0.06$ & $4.14 \pm 0.31$ & $3.51 \pm 0.09$ & $2.13 \pm 0.53$ \\
Lung & $7.34 \pm 0.37$ & $4.03 \pm 0.27$ & $3.61 \pm 0.72$ & $1.87 \pm 0.20$ \\
Kidney & $6.18 \pm 0.94$ & $4.81 \pm 0.47$ & $3.25 \pm 0.21$ & $6.15 \pm 0.72$ \\
Intestine & $5.21 \pm 0.44$ & $8.22 \pm 0.02$ & $3.80 \pm 0.89$ & $3.76 \pm 0.68$ \\
Heart & $5.75 \pm 0.92$ & $2.31 \pm 0.55$ & $2.16 \pm 0.27$ & $1.07 \pm 0.08$ \\
Muscle & $2.33 \pm 0.33$ & $1.54 \pm 0.49$ & $0.75 \pm 0.11$ & $0.37 \pm 0.08$ \\
Spleen & $4.76 \pm 0.43$ & $5.01 \pm 0.80$ & $3.88 \pm 0.24$ & $2.88 \pm 0.26$ \\
Tumor & $3.52 \pm 0.59$ & $11.58 \pm 1.07$ & $4.08 \pm 0.04$ & $2.22 \pm 0.01$ \\
\hline
\end{tabular}

The values are average of $\%$ injected dose/gram $\pm \operatorname{SD}$ for $n=4$.

${ }^{*}$ Animals were injected with ${ }^{67} \mathrm{Ga}-[\mathrm{APSC}]_{2}$ radiotracer.

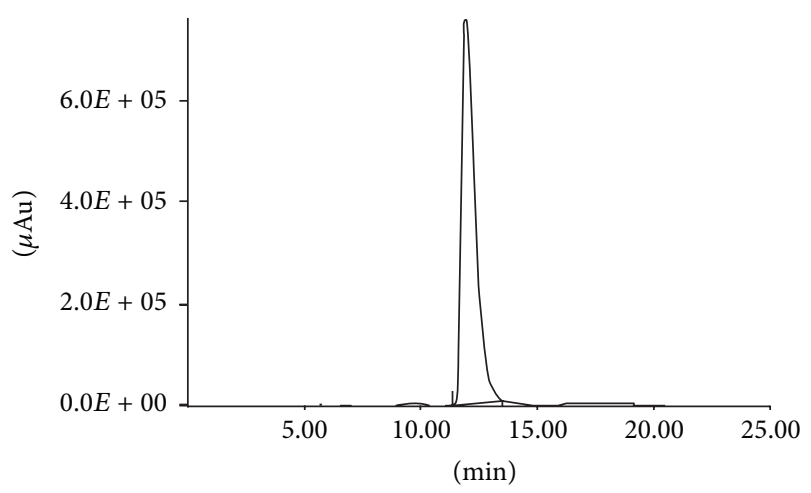

FIGURE 1: HPLC chromatogram of Ga-(2-acetylpyridine semicarbazone $)_{2}$ complex (Ga- $[\mathrm{APSC}]_{2}$ ).

increased with time. However, the accumulation of ${ }^{68} \mathrm{Ga}$ [APSC $]_{2}$ tracer in most of the other organs revealed that it is at least twofold lower than the tracer ${ }^{67} \mathrm{Ga}$-thiosemicarbazone
[20]. Thus, the good tumor targeting capabilities together with the favorable biodistribution profile of ${ }^{68} \mathrm{Ga}-[\text { APSC }]_{2}$ warrant further evaluation and may tempt one to infer that this PET radiotracer may be useful as a molecular probe for detecting and staging of hypoxic tumors and their metastasis as well as monitoring tumor response to treatment.

\section{Conclusion}

${ }^{68} \mathrm{Ga}-[\mathrm{APSC}]_{2}$ was synthesized in quantitative radiochemical yield and purity in less than $60 \mathrm{~min}$. Biodistribution results of ${ }^{68} \mathrm{Ga}$-[APSC] $]_{2}$ in nude mice model bearing human MDAMB-231 cell line xenografts demonstrated significant tumor uptake at $2 \mathrm{~h}$ p.i. and favorable pharmacokinetics over previously investigated ${ }^{67} \mathrm{Ga}$-[APSC] ${ }_{2}$ radiotracer. These results demonstrate that ${ }^{68} \mathrm{Ga}$-[APSC] $]_{2}$ radiotracer may be useful as PET probe for detecting and staging of hypoxic tumor; however, further evaluation is warranted. 


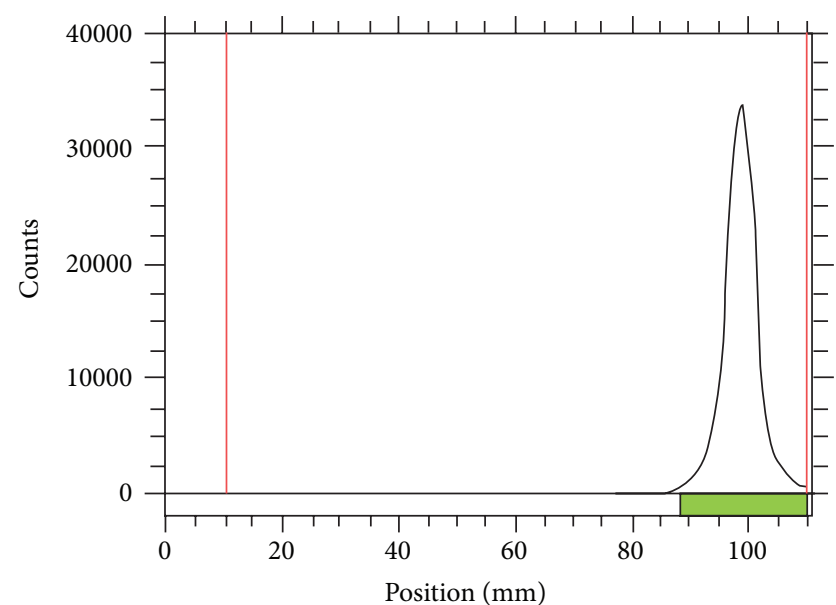

FIgURE 2: TLC chromatogram of ${ }^{68} \mathrm{Ga}$-(2-acetylpyridine semicarbazone $)_{2}$ complex $\left({ }^{68} \mathrm{Ga}-[\mathrm{APSC}]_{2}\right)$.

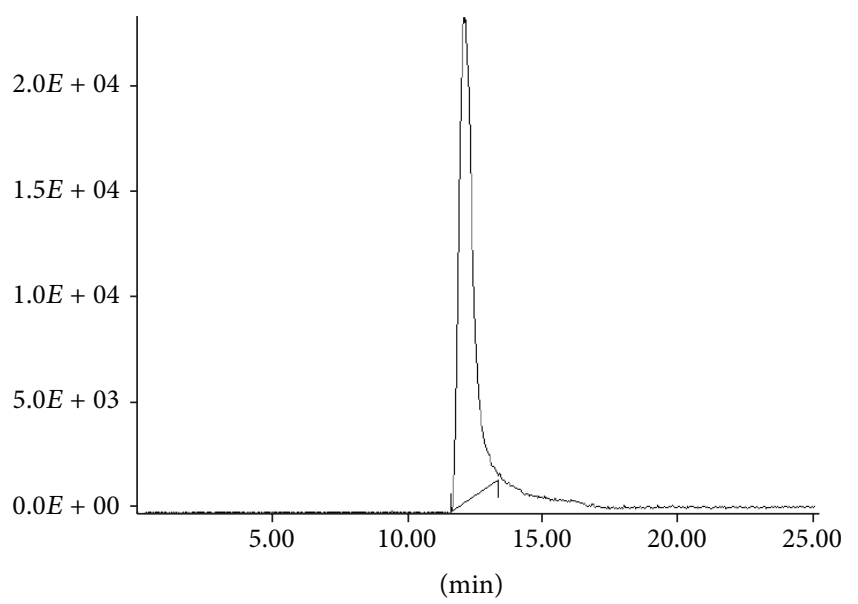

(a)

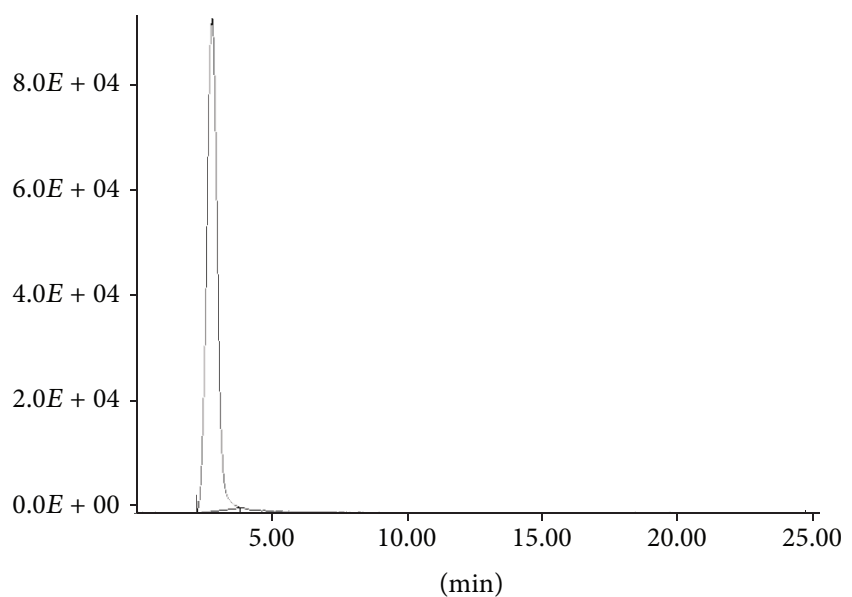

(b)

FIGURE 3: HPLC chromatograms of ${ }^{68} \mathrm{Ga}$-(2-acetylpyridine semicarbazone $)_{2}$ complex $\left({ }^{68} \mathrm{Ga}-[\text { APSC }]_{2}\right)$ (a) and ${ }^{68} \mathrm{GaCl}_{3}$ (b).

\section{Conflict of Interests}

The authors declare that there is no conflict of interests regarding the publication of this paper.

\section{Acknowledgments}

The research team would like to acknowledge the King Faisal Specialist Hospital and Research Center (KFSH\&RC) and the International Atomic Energy Agency (IAEA) for their support. This research project was partially supported by a grant from the "Research Center of the Center for Female Scientific and Medical Colleges," Deanship of Scientific Research, King Saud University. Also, special thanks are due to the comparative medicine department for their support in animal studies.

\section{References}

[1] V. B. Arion, M. A. Jakupec, M. Galanski, P. Unfried, and B. K. Keppler, "Synthesis, structure, spectroscopic and in vitro antitumour studies of a novel gallium(III) complex with 2-acetylpyridine 4N-dimethylthiosemicarbazone," Journal of Inorganic Biochemistry, vol. 91, no. 1, pp. 298-305, 2002.

[2] I. C. Mendes, M. A. Soares, R. G. dos Santos, C. Pinheiro, and H. Beraldo, "Gallium(III) complexes of 2-pyridineformamide thiosemicarbazones: cytotoxic activity against malignant glioblastoma," European Journal of Medicinal Chemistry, vol. 44, no. 5, pp. 1870-1877, 2009.

[3] T. S. Lobana, R. Sharma, G. Bawa, and S. Khanna, "Bonding and structure trends of thiosemicarbazone derivatives of metals-an overview," Coordination Chemistry Reviews, vol. 253, no. 7-8, pp. 977-1055, 2009.

[4] J. Chan, A. L. Thompson, M. W. Jones, and J. M. Peach, "Synthesis and structural studies of gallium(III) and indium(III) complexes of 2-acetylpyridine thiosemicarbazones," Inorganica Chimica Acta, vol. 363, no. 6, pp. 1140-1149, 2010.

[5] E. Bermejo, R. Carballo, A. Castineiras et al., "Synthesis, structural characteristics and biological activities of complexes of ZnII, CdII, HgII, PdII, and PtII with 2-acetylpyridine 4-methylthiosemicarbazone," European Journal of Inorganic Chemistry, vol. 6, pp. 965-973, 1999.

[6] B. K. Rai, P. Choudhary, S. Rana, and P. Sahi, "Structural characterization and antifungal studies of some mixed ligand schiff base complexes with 6-bromo-2- thio 3-phenyl quinazoline$4(3 \mathrm{H})$ one thiosemicarbazone," Oriental Journal of Chemistry, vol. 23, pp. 271-275, 2007.

[7] M. C. Rodríguez-Argüelles, P. Tourón-Touceda, R. Cao et al., "Complexes of 2 -acetyl- $\gamma$-butyrolactone and 2furancarbaldehyde thiosemicarbazones: antibacterial and antifungal activity," Journal of Inorganic Biochemistry, vol. 103, no. 1, pp. 35-42, 2009.

[8] D. X. West, A. M. Stark, G. A. Bain, and A. E. Liberia, "Copper(II) complexes of 2-formyl-, 6-methyl-2-formyl- And 2-benzoylpyridine $N(4)$-(2-methylpyridinyl)-,N(4)-(2-ethylpyridinyl)- and $N(4)$-methyl(2-ethylpyridinyl)thiosemicarbazones," Transition Metal Chemistry, vol. 21, no. 4, pp. 289-295, 1996.

[9] B. S. Yadav, V. Kumar, and M. K. Yadav, "Vibrational spectra, thermodynamic parameters and fungicidal activity of 2hydroxy-3-methoxybenzaldehyde thiosemicarbazone," Indian 
Journal of Pure and Applied Physics, vol. 36, no. 10, pp. 557-566, 1998.

[10] J. Easmon, G. Pürstinger, G. Heinisch et al., "Synthesis, cytotoxicity, and antitumor activity of copper(II) and iron(II) complexes of $4 \mathrm{~N}$-azabicyclo[3.2.2] nonane Thiosemicarbazones derived from acyl diazines," Journal of Medicinal Chemistry, vol. 44, no. 13, pp. 2164-2171, 2001.

[11] R. A. Finch, M.-C. Liu, A. H. Cory, J. G. Cory, and A. C. Sartorelli, "Triapine (3-aminopyridine-2-carboxaldehyde thiosemicarbazone; 3-AP): an inhibitor of ribonucleotide reductase with antineoplastic activity," Advances in Enzyme Regulation, vol. 39, pp. 3-12, 1999.

[12] N. Adonai, K. N. Nguyen, J. Walsh et al., "Ex vivo cell labeling with 64Cu-pyruvaldehyde-bis(N4-methylthiosemicarbazone) for imaging cell trafficking in mice with positron-emission tomography," Proceedings of the National Academy of Sciences of the United States of America, vol. 99, no. 5, pp. 3030-3035, 2002.

[13] Y. Fujibayashi, H. Taniuchi, Y. Yonekura, H. Ohtani, J. Konishi, and A. Yokoyama, "Copper-62-ATSM: a new hypoxia imaging agent with high membrane permeability and low redox potential," Journal of Nuclear Medicine, vol. 38, no. 7, pp. 1155-1160, 1997.

[14] Y. Fujibayashi, C. S. Cutler, C. J. Anderson et al., "Comparative studies of Cu-64-ATSM and C-11-acetate in an acute myocardial infarction model: ex vivo imaging of hypoxia in rats," Nuclear Medicine and Biology, vol. 26, no. 1, pp. 117-121, 1999.

[15] F. Dehdashti, M. A. Mintun, J. S. Lewis et al., "In vivo assessment of tumor hypoxia in lung cancer with 60Cu-ATSM," European Journal of Nuclear Medicine and Molecular Imaging, vol. 30, no. 6, pp. 844-850, 2003.

[16] F. Dehdashti, P. W. Grigsby, J. S. Lewis, R. Laforest, B. A. Siegel, and M. J. Welch, "Assessing tumor hypoxia in cervical cancer by PET with $60 \mathrm{Cu}$ - labeled diacetyl-bis(N4methylthiosemicarbazone)," Journal of Nuclear Medicine, vol. 49, no. 2, pp. 201-205, 2008.

[17] J. S. Lewis, T. L. Sharp, R. Laforest, Y. Fujibayashi, and M. J. Welch, "Tumor uptake of copper-diacetyl-bis (n4methylthiosemicarbazone): effect of changes in tissue oxygenation," Journal of Nuclear Medicine, vol. 42, no. 4, pp. 655-661, 2001.

[18] F. Haghighi Moghadam, A. R. Jalilian, A. Nemati, and M. Abedini, "Preparation and biodistribution studies of [67Ga]2acetylpyridine 4,4-dimethyl thiosemicarbazone complex as a possible SPECT tracer for detection of malignancies," Journal of Radioanalytical and Nuclear Chemistry, vol. 272, no. 1, pp. 115121, 2007.

[19] A. R. Jalilian, H. Yousefnia, K. Shafaii, A. Novinrouz, and A. A. Rajamand, "Preparation and biodistribution studies of a radiogallium-acetylacetonate bis (thiosemicarbazone) complex in tumor-bearing rodents," Iranian Journal of Pharmaceutical Research, vol. 11, no. 2, pp. 523-531, 2012.

[20] A. R. Jalilian, P. Mehdipour, M. Akhlaghi, H. Yousefnia, and K. Shafaii, "Evaluation of a $\left[{ }^{67} \mathrm{Ga}\right]$-thiosemicarbazone complex as tumor imaging agent," Scientia Pharmaceutica, vol. 77, no. 2, pp. 343-354, 2009.

[21] S. Delagrange, R. Delgado, and F. Nepveu, " $\mathrm{Mn}^{2+}, \mathrm{Co}^{2+}, \mathrm{Cu}^{2+}$ and $\mathrm{Zn}^{2+}$ complexes with two macrocyclic ligands bearing $\mathrm{L}-$ lactate-like functions: potentiometric studies and evaluation of superoxide-scavenging properties of the $\mathrm{Mn}^{2+}$ complex," Journal of Inorganic Biochemistry, vol. 81, no. 1-2, pp. 65-71, 2000 .
[22] P.-D. Pilar, P. Souza, J. R. Masaguer, and A. Arquero, "Complexes of 2-acetylpyridinesemicarbazone and 2-acetylpyridinethiosemicarbazone with cobalt(II), chromium(III) and copper(II)," Transition Metal Chemistry, vol. 12, no. 3, pp. 200-202, 1987.

[23] W. A. P. Breeman, M. De Jong, E. De Blois, B. F. Bernard, M. Konijnenberg, and E. P. Krenning, "Radiolabelling DOTApeptides with 68Ga," European Journal of Nuclear Medicine and Molecular Imaging, vol. 32, no. 4, pp. 478-485, 2005.

[24] K. P. Zhernosekov, D. V. Filosofov, R. P. Baum et al., "Processing of generator-produced $68 \mathrm{Ga}$ for medical application," Journal of Nuclear Medicine, vol. 48, no. 10, pp. 1741-1748, 2007.

[25] Guide for the Care of and Use of Laboratory Animals, National Academy Press, Washington, DC, USA, 1996.

[26] L. Li and Y. Lu, "Inhibition of hypoxia-induced cell motility by p16 in MDA-MB-231 breast cancer cells," Journal of Cancer, vol. 1, no. 1, pp. 126-135, 2010.

[27] C. L. Morton and P. J. Houghton, "Establishment of human tumor xenografts in immunodeficient mice," Nature Protocols, vol. 2, no. 2, pp. 247-250, 2007. 

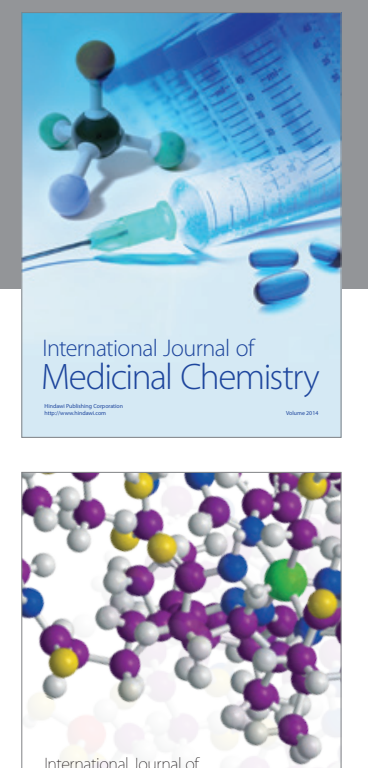

\section{Carbohydrate} Chemistry

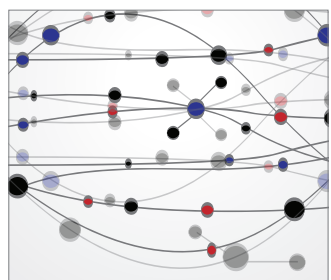

The Scientific World Journal
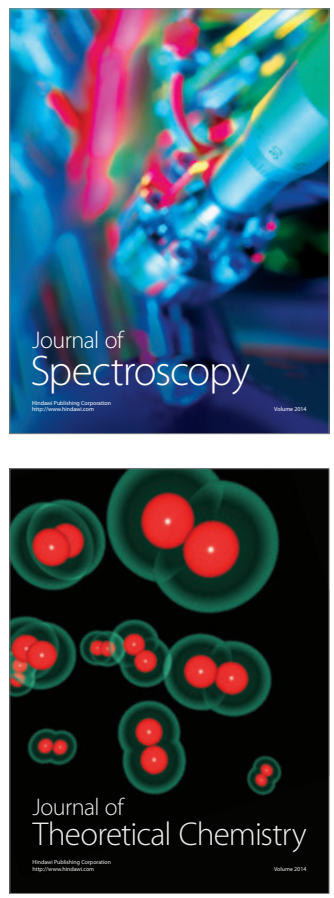
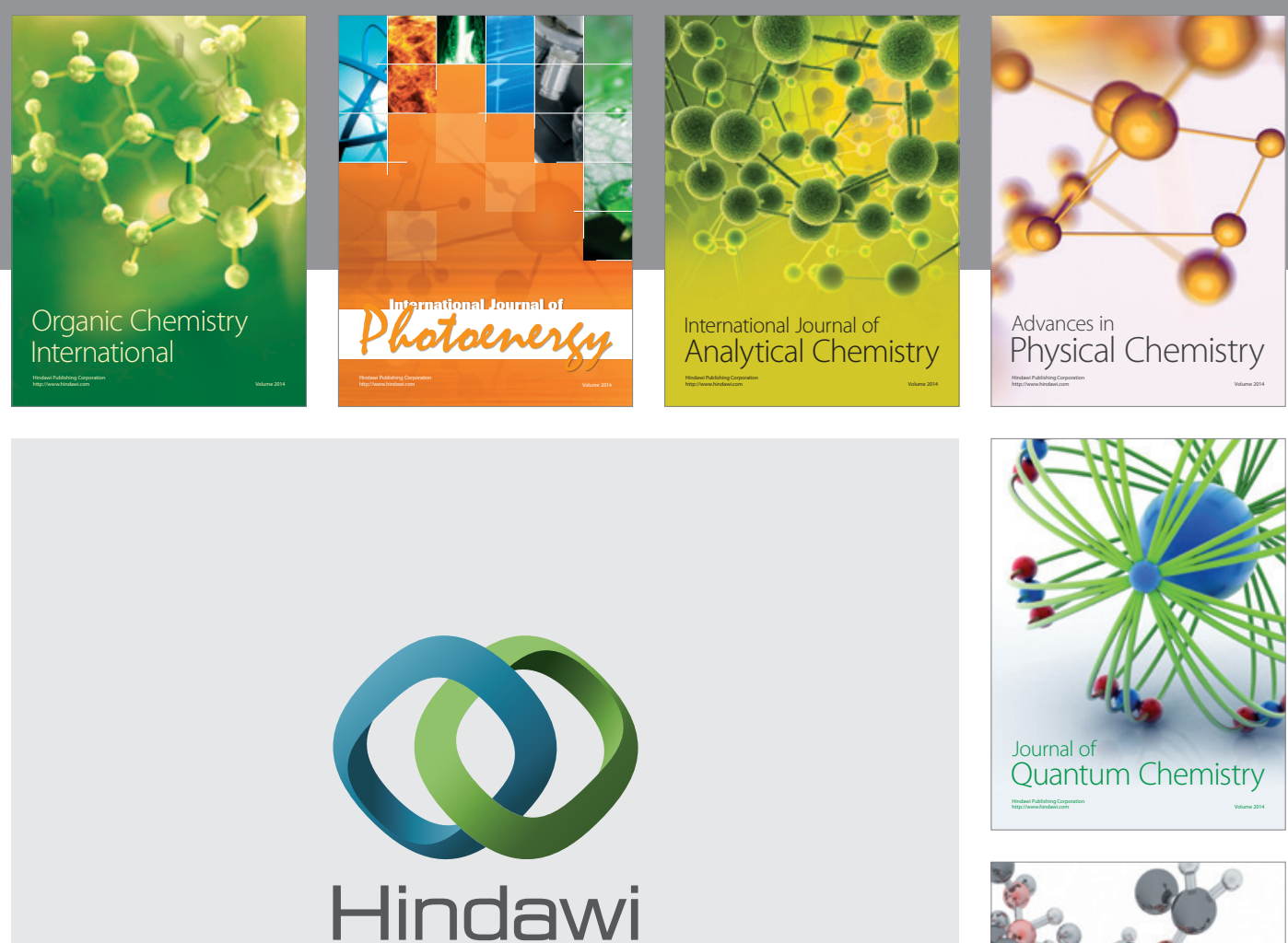

Submit your manuscripts at

http://www.hindawi.com

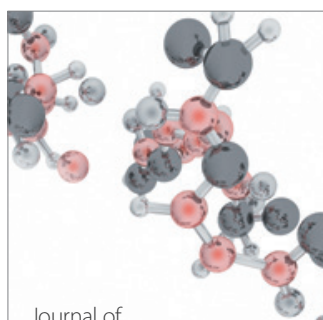

Analytical Methods

in Chemistry

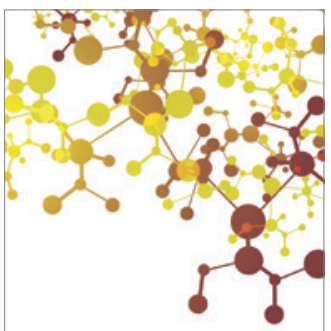

Journal of

Applied Chemistry

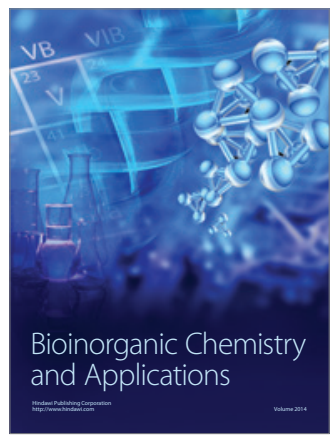

Inorganic Chemistry
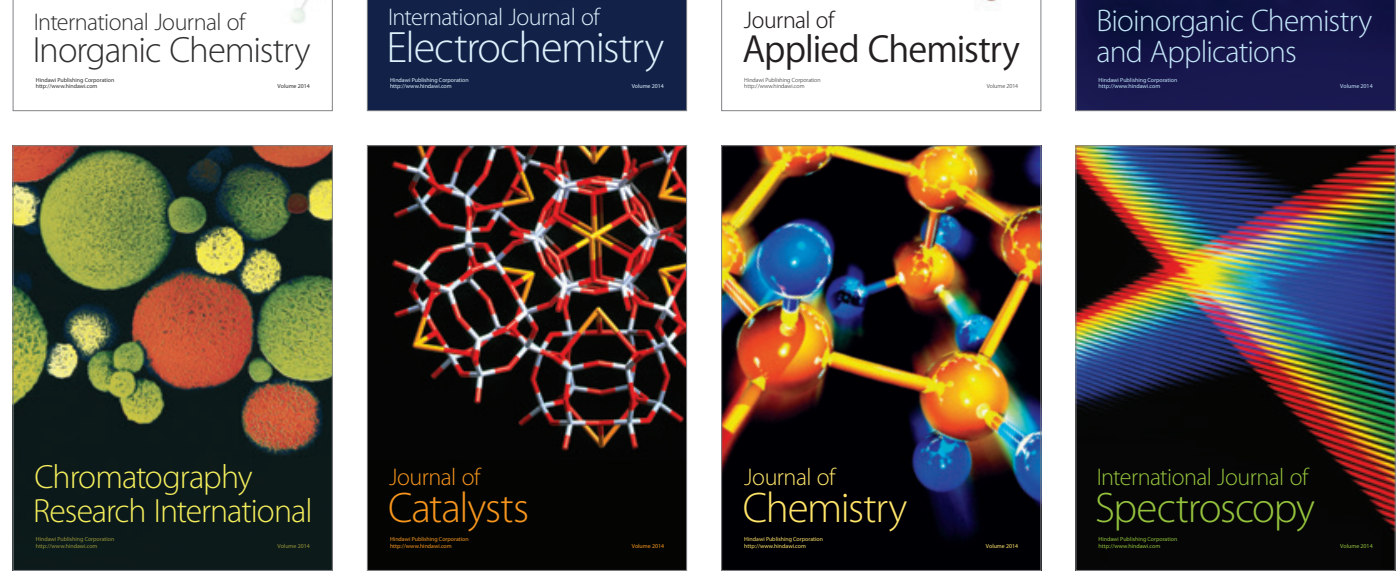